\title{
Genetic and environmental nature of the insulin resistance syndrome in Indo-Mauritian subjects with premature coronary heart disease: contribution of $\beta 3$-adrenoreceptor gene polymorphism and beta blockers on triglyceride and HDL concentrations
}

\author{
M.Manraj ${ }^{1}$, S. Francke ${ }^{3}$, A.Hébé ${ }^{1}$, U.S. Ramjuttun ${ }^{2}$, P. Froguel ${ }^{3}$ \\ ${ }^{1}$ SSR Centre for Medical Studies and Research, University of Mauritius, Moka, Mauritius \\ ${ }^{2}$ Ministry of Health, Mauritius \\ ${ }^{3}$ Institute of Biology-CNRS 8090, Pasteur Institute of Lille, France
}

\section{Abstract}

Aims/hypothesis. Insulin resistance syndrome is an important risk factor for developing premature coronary heart disease. It is a complex syndrome which could arise from the interaction of several genes modulated by environmental factors. The Trp64Arg polymorphism in the $\beta 3$-adrenoreceptor gene has been found to be associated with insulin resistance, obesity or with earlier onset of Type II (non-insulin-dependent) diabetes mellitus in different populations. We aimed to study whether features of the insulin resistance syndrome are associated with this polymorphism in Indo-Mauritian patients with premature coronary heart disease.

Methods. We carried out a case control study using PCR-RFLP techniques, of consecutive Indo-Mauritian patients $(n=338)$ with premature coronary heart disease (onset below age of 60 years) and unrelated control subjects $(n=148)$ of the same ethnicity.

Results. In Indo-Mauritian patients with premature coronary heart disease who were not treated by beta blockers, triglyceride concentrations were lower (me- dian: 1.44 vs $1.93 \mathrm{mmol} / \mathrm{l}, p<0.008)$ and HDL cholesterol concentrations higher (mean: 0.98 vs $0.85 \mathrm{mmol} / \mathrm{l}$, $p<0.015$ ) in those carrying the wild type of the $\beta 3$ adrenoreceptor gene than in those carrying the Trp64Arg variant. The latter genotype specific effect on HDL was inverse in patients treated with beta blockers.

Conclusion/interpretation. The $\beta 3$-adrenoreceptor gene variant seems to modulate the effects of beta blockers on triglyceride and HDL cholesterol concentrations in this group of Indo-Mauritian population. Dyslipidaemia, a key component of the metabolic syndrome has a heterogeneous nature in IndoMauritian subjects. This potent risk factor for earlyonset coronary heart disease is influenced by the interaction between genetic and environmental effects. [Diabetologia (2001) 44: 115-122]

Keywords Indo-Mauritian population, CHD, Type II diabetes mellitus, insulin resistance, $\beta 3$-adrenergicreceptor polymorphism, HDL cholesterol, triglyceride concentration, beta blocker.
Received: 29 June 2000 and in revised form: 4 September 2000

Corresponding author: Dr M. Manraj, SSR Centre for Medical Studies and Research, University of Mauritius, Moka, Mauritius (Indian Ocean)

Abbreviations: WHR, Waist-to-hip ratio; AGM, abnormal glucose metabolism (individuals with impaired fasting glycaemia, impaired glucose tolerance or Type II diabetes); HOMA, homeostasis model assessment; FPG, fasting plasma glucose; $\mathrm{BB}$, beta blocker; (BB-), patient not treated with $\mathrm{BB}$; $(\mathrm{BB}+)$, patient treated with $\mathrm{BB} ; \mathrm{TG}$, triglycerides.
Several studies have documented high rates of coronary heart disease (CHD) among migrants from the Indian subcontinent [1]. The common risk factors shared by these communities are increased plasma triglyceride concentrations, decreased high density lipoprotein (HDL) cholesterol, high fasting and post-glucose insulin concentrations, central obesity and a high prevalence of Type II (non-insulin-dependent) diabetes mellitus. These features, found consistently in Indian communities settled overseas, reflect an underlying state of insulin resistance [2]. The majority of the Mauritian population, $70 \%$, are descen- 
dants of the Indian diaspora, from North-East India (migration from the port of Calcutta) and from South India (from the port of Madras) which began in the mid $19^{\text {th }}$ century. Metabolic abnormalities associated with the insulin resistance syndrome (IRS) have been shown to cluster in the Mauritian population [3]. This syndrome, also called the metabolic syndrome, could arise from the interaction of a few genes (oligogenic) or several genes (multigenic) modulated by environmental factors.

A candidate gene for IRS is the $\beta 3$-adrenoreceptor gene with the Trp64Arg polymorphism which has shown an association with earlier onset of Type II diabetes, with lower resting metabolic rate in Pima Indians [4] and with earlier onset of Type II diabetes and IRS in non-diabetic subjects from West Finland [5]. The genetic variation in the $\beta 3$-adrenergic receptor was also associated with an increased capacity for weight gain in patients with morbid obesity in a French study [6] and with obesity among MexicanAmericans [7]. Recently proliferative retinopathy was associated with this polymorphism in Japanese diabetes patients [8]. Moreover, in this group of Japanese, subjects carrying the variant had an earlier onset of Type II diabetes, higher BMI values, increased serum triglyceride and decreased HDL concentrations than the non-carriers, suggesting that they could be more insulin resistant. To study whether the Trp64Arg polymorphism was associated with features of IRS in Mauritius, we carried out a comparative study between unrelated patients with premature CHD (onset at age 60) and unrelated control subjects in a subgroup of the Mauritian population.

\section{Subjects and methods}

We recruited 338 consecutive unrelated Indo-Mauritian patients, descendants of North-East Indian immigrants, (290 men, 48 women, mean age $48, \mathrm{SD}=7$ ) with premature coronary heart disease (mean age of onset $45, \mathrm{SD}=7$ ). They were followed-up in coronary care units of two public hospitals in Mauritius and 148 unrelated control subjects were matched for ethnicity ( 120 men and 28 women, mean age $44, \mathrm{SD}=8$ ). We considered as positive for $\mathrm{CHD}$ a previous diagnosis of myocardial infarction (MI) based on the existence of at least two of the following criteria: chest pain for more than $30 \mathrm{~min}$, ECG patterns of acute MI, increased cardiac enzymes (a history of revascularisation procedure such as angioplasty or coronary artery bypass grafts), and documented treatment for angina pectoris.

Our study was carried out in accordance with the Declaration of Helsinki [9] and all participating subjects gave their informed written consent. They answered detailed personal and medical family history questionnaires, and research-clinic evaluations were carried out: fasting blood samples (for lipid measurements of total cholesterol, triglycerides, HDL cholesterol), an oral glucose tolerance test (OGTT with $75 \mathrm{~g}$ of glucose given to subjects who had no known diabetes) with fasting and 2-h blood samples for glucose and insulin measurements, anthropometric and blood pressure (BP) measurements, inter- views with the physicians and physical examinations. An early morning midstream sample was analysed on the same day for albuminuria and for microalbumiuria if albuminuria was nil. An electrocardiogram (ECG) was carried out for control subjects and recorded in the patients' follow-up hospital records. We collected 10 to $20 \mathrm{ml}$ of total blood on EDTA from all the participants for DNA extraction.

Biochemical and other measurements. Blood glucose, total cholesterol, triglycerides, uric acid and HDL cholesterol were assayed by enzymatic colorimetric methods using a multiparametric auto-analyser (Cobas Mira Plus, Roche Diagnostics Systems, Neuilly-sur-Seine, France) and reagent kits for the assays (Randox Laboratory, Crumlin, UK). Quantitative measurements of plasma insulin were carried out using double antibody radio-immunoassays (Eria Diagnostics Pasteur, Marnes la Coquette, France). Albuminuria was tested by reagent strips (BM-Test-GP, Boehringer-Mannheim, Mannheim, Germany). Microalbuminuria was tested by the Micral-Test strip method, a semi-quantitative test, based on a specific immunocapture technique (Micral-Test II, Boehringer-Mannheim). The DNA were extracted by the salting out method.

Characterisation of glucose metabolism status, homeostasis model assessment (HOMA) score and hypertensive status. We used a combination of personal history, fasting plasma glucose (FPG) and 2-h plasma glucose (2hPG) measurements to determine normal glucose tolerance (NGT), impaired fasting glucose (IFG), impaired glucose tolerance (IGT) or Type II diabetes (NGT if FPG $<6.1 \mathrm{mmol} / \mathrm{l}$ and $2 \mathrm{hPG}<7.8 \mathrm{mmol} / \mathrm{l}$; IFG if $\mathrm{FPG} \geq 6.1$ and $<7 \mathrm{mmol} / \mathrm{l}$ and $2 \mathrm{hPG}<7.8 \mathrm{mmol} / \mathrm{l}$; IGT if $\mathrm{FPG}<7 \mathrm{mmol} / 1$ and $2 \mathrm{hPG} \geq 7.8 \mathrm{mmol} / 1$ and $<11.1 \mathrm{mmol} / \mathrm{l}$; Type II diabetes: if previous history of diabetes; if $\mathrm{FPG} \geq$ $7 \mathrm{mmol} / \mathrm{l}$; or if $\mathrm{FPG}<7 \mathrm{mmol} / \mathrm{l}$ and $2 \mathrm{hPG} \geq 11.1 \mathrm{mmol} / \mathrm{l})$.

Abnormal glucose metabolism (AGM) includes IFG, IGT and Type II diabetes. Control subjects had no detectable coronary heart disease and no AGM.

Homeostasis model assessment (HOMA) [10] scores were calculated for subjects who were not treated by hypoglycaemic agents $[$ HOMA score $=$ fasting insulin $(\mu \mathrm{U} / \mathrm{ml}) \times$ FPG $(\mathrm{mmol} / \mathrm{l})$ divided by 22.5].

Subjects were considered to be hypertensive if they had a documented history of high blood pressure, or if either their systolic blood pressure was 140 or more or their diastolic blood pressure was $90 \mathrm{~mm} \mathrm{Hg}$ or more.

Characterisation of IRS or metabolic syndrome. We used the definition of the metabolic syndrome recently published in a World Health Organization (WHO) report [11] to evaluate the importance of this syndrome. Subjects were considered positive for the metabolic syndrome if they had an AGM or if their HOMA score was in the 75th centile range or higher (the HOMA score is considered a reliable surrogate measure of in vivo insulin sensitivity in humans [12] and the 75th centile of HOMA score was defined in the control group), together with two or more of the following components:

(1) raised arterial pressure of $140 / 90 \mathrm{~mm} \mathrm{Hg}$ or higher. (2) raised plasma triglycerides $(\geq 1.7 \mathrm{mmol} / \mathrm{l})$ and/or low HDL cholesterol (men $<0.9 \mathrm{mmol} / \mathrm{l}$, women 1.0 and using these cut-off values, we defined qualitative varibles such as hypertriglyceridaemia and low-HDL, (3) central obesity [waist-to-hip ratio $($ WHR) $>0.90$ in men and $>0.85$ in women] or a BMI greater than $30 \mathrm{~kg} / \mathrm{m}^{2}$, or both and (4) microalbuminuria greater than or equal to $20 \mathrm{mg} / \mathrm{l}$. Microalbuminuria greater than or equal to $20 \mathrm{mg} / \mathrm{l}$. 
Table 1. Comparison between patients with coronary heart disease and control subjects

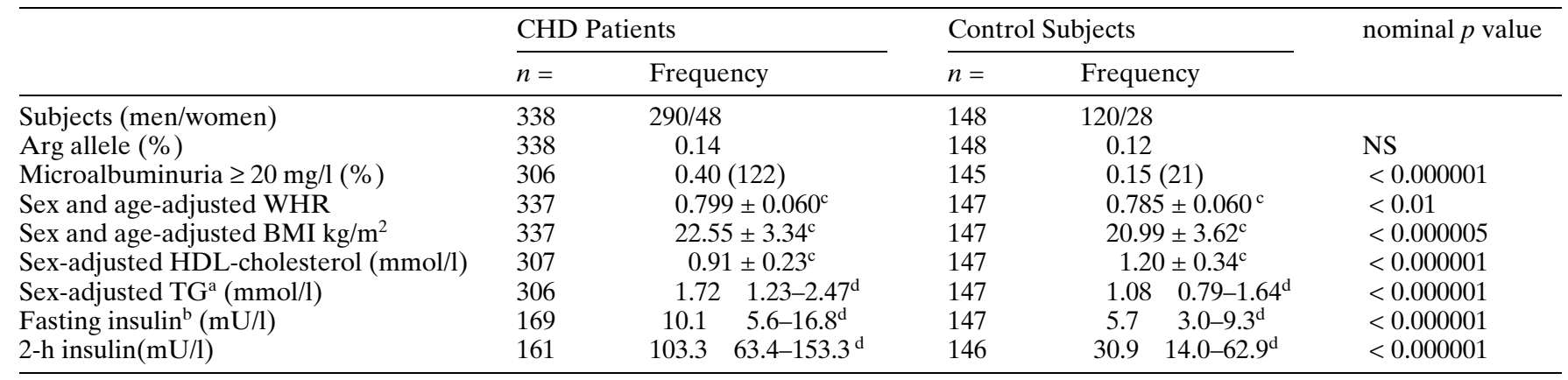

a Subjects receiving pharmacological treatment for dyslipidaemia excluded

${ }^{\mathrm{b}}$ Subjects receiving pharmacological treatment for Type II dia-

betes excluded
Study of the Trp64Arg polymorphism in the $\beta 3$-adrenegic receptor. The Trp64Arg polymorphism in the $\beta 3$-adrenergic receptor was studied using PCR-RFLP techniques on genomic DNA extracted from the subjects' peripheral blood leucocytes. We used the following primer pair:

5'-CCAGTGGGCTGCCAGGGG-3', 5'-GCCAGTGGCGCCCAACGG3'

to amplify a 248 bp PCR product which was cleaved by BstN1 (the Trp64Arg mutation eliminates one restriction cleavage site) using the same protocol as described previously (6).

Statistical analyses. We used the statistical package Epi-info 6 (CDC, Atlanta, Ga., USA) for statistical analyses. We evaluated the association between categorical variables and the Trp64Arg polymorphism with a chi-squared test. Normally distributed variables between group differences were tested by the two-way unpaired student's $t$ test. Kruskal-Wallis nonparametric tests were used to compare quantitative variables which did not follow a normal distribution or when variances between groups were not homogeneous. Results for quantitative variables are given as means \pm SD. For those which do not follow a normal distribution, such as insulin and triglycerides concentrations, results are given as median (25th-75th centile). Stratified analyses using Mantel-Haenzel chi-squared test were carried out to evaluate the association between the Trp64Arg polymorphism and variables associated with IRS and to evaluate the possible interactions between the betablocker treatment and the $\beta 3$-adrenergic-receptor polymorphism on these variables. Results in the stratified analyses are given as odds ratio (OR) with Cornfield $95 \%$ confidence interval (CI) for the OR, and $p$ value for Yates corrected chisquared for each contingency table. Comparison between contingency tables yielded a chi-squared and $p$ value for interaction evaluations. A $p$ value of less than 0.05 was considered significant.

\section{Results}

We compared risk factors associated with the metabolic syndrome between patients and control subjects (Table 1). Before we made the comparison, HDL cholesterol and triglyceride concentrations were adjusted for sex (no correlation was found between age
${ }^{\mathrm{c}} \mathrm{SD} \pm$

d $25^{\text {th }}-75^{\text {th }}$ centile

and HDL cholesterol or triglyceride concentrations) and waist-to-hip ratio (WHR) and BMI were adjusted for age and sex. As expected, patients $(n=338)$ had significantly higher WHR, a higher BMI, a higher fasting and 2-h insulin, increased triglyceride and decreased HDL cholesterol concentrations than control subjects $(n=148)$. Albuminuria or microalbuminuria $(\geqslant 20 \mathrm{mg} / \mathrm{l})$ were found in $40 \%$ of patients with coronary heart disease compared with $15 \%$ in the control subjects $\left(p<10^{-6}\right)$. Moreover $176 \mathrm{CHD}$ patients $(52 \%)$ were hypertensive, 178 had an AGM $(53 \%)$ and 110 had both HBP and AGM (33\%). Patients with coronary heart disease $(n=162,48 \%)$ had a metabolic syndrome as defined by the recently published criteria of the WHO. Obesity was defined as a BMI of more than $30 \mathrm{~kg} / \mathrm{m}^{2}$ and was not a feature frequently encountered in CHD patients $(4 \%)$ compared with central obesity $(51 \%)$, however $93 \%$ of these obese patients showed a cluster of risk factors associated with the metabolic syndrome (Table 2).

Genotypes in both groups were in Hardy-Weinberg equilibrium. Frequencies for genotypes (TT, TA and AA) were similar between patients $(249,82$, 7 , respectively) and control subjects $(112,36,0$, respectively), suggesting no association between CHD and $\beta 3$-adrenergic-receptor polymorphism. Carriers for the mutation (TA and AA) in patients and control subjects were grouped against subjects with the wild type (TT). No association was found between the Trp64Arg variant with either AGM or high blood pressure or with the metabolic syndrome in the patient group. No statistically significant differences were observed for BMI, WHR or insulin values for carriers of the variant in either group.

After excluding subjects who took hypolipaemic drugs, we analysed possible genotype-specific effects of the variant on triglyceride and HDL concentrations. We observed a trend towards higher triglyceride concentrations in control subjects carrying the variant $(n=36),[1.22(0.75-1.84)$ vs $0.95(0.68-1.48)$ $\mathrm{mmol} / \mathrm{l}, p<0.09$ ] compared with control subjects' ho- 
Table 2. Evaluation of components of the metabolic syndrome in patients with coronary heart disease

\begin{tabular}{|c|c|c|c|c|c|}
\hline Components of metabolic syndrome & $n=$ & $\begin{array}{l}\text { Prevalence } \\
\text { of component } \\
\text { in CHD group }\end{array}$ & $\begin{array}{l}\text { Prevalence } \\
\text { of metabolic } \\
\text { syndrome when } \\
\text { component } \\
\text { is present }\end{array}$ & Odds ratio & $95 \% \mathrm{CI}$ for OR \\
\hline AGM & 338 & $0.53(178)$ & $0.76(135)$ & 15.47 & $8.70<\mathrm{OR}<27.68$ \\
\hline HOMA score $>75$ th centile & 169 & $0.58(98)$ & $0.52(51)$ & 11.76 & $4.34<\mathrm{OR}<33.64$ \\
\hline $\begin{array}{l}\text { Low-HDL }(\mathrm{HDL}<0.90 \text { in men } \\
\text { and HDL }<1.0 \mathrm{mmol} / 1 \text { in women })\end{array}$ & 307 & $0.53(162)$ & $0.54(88)$ & 1.84 & $1.13<\mathrm{OR}<2.98$ \\
\hline $\begin{array}{l}\text { Central obesity (WHR }>0.90 \text { in men } \\
\text { and WHR }>0.85 \text { in women) }\end{array}$ & 337 & $0.51(173)$ & $0.63(109)$ & 3.57 & $2.21<\mathrm{OR}<5.77$ \\
\hline Obesity $\left(\mathrm{BMI}>30 \mathrm{~kg} / \mathrm{m}^{2}\right)$ & 337 & $0.04(14)$ & $0.93(13)$ & 15.18 & $2.01<\mathrm{OR}<31.9$ \\
\hline
\end{tabular}

Table 3. Genotype specific distributions of triglyceride, HDL concentrations, waist girth and BMI in CHD patients in relation to their $\beta 3$-adrenergic-receptor genotype and BB treatment

\begin{tabular}{|c|c|c|c|c|c|}
\hline & \multicolumn{2}{|c|}{ TT genotype } & \multicolumn{2}{|c|}{ TA + AA genotypes } & \multirow{2}{*}{$\begin{array}{l}\text { nominal } \\
p \text { value }\end{array}$} \\
\hline & $n=$ & $\begin{array}{l}\text { Mean } \pm S D \text { or Median } \\
\left(25^{\text {th }}-75^{\text {th }}\right) \text { centile }\end{array}$ & $n=$ & $\begin{array}{l}\text { Mean } \pm S D \text { or Median } \\
\left(25^{\text {th }}-75^{\text {th }}\right) \text { centile }\end{array}$ & \\
\hline $\mathrm{CHD}$ patients $(\mathrm{BB}+)$ & 125 & $1.76(1.24-2.60)$ & 48 & $1.55(1.13-2.59)$ & 0.77 \\
\hline CHD patients (BB-) & 95 & $1.44(1.01-2.10)$ & 32 & $1.93(1.40-3.04)$ & 0.008 \\
\hline $\mathrm{CHD}$ patients $(\mathrm{BB}+)$ & 124 & $0.88 \pm 0.20$ & 47 & $0.98 \pm 0.23$ & 0.01 \\
\hline CHD patients (BB-) & 95 & $0.98 \pm 0.26$ & 32 & $0.85 \pm 0.24$ & 0.015 \\
\hline $\begin{array}{l}\text { Waist girth }(\mathrm{cm}) \\
\text { All CHD patients }\end{array}$ & 249 & $88.1 \pm 8.8$ & 89 & $89.7 \pm 8.8$ & 0.14 \\
\hline CHD patients $(\mathrm{BB}+)$ & 135 & $89.0 \pm 8.0$ & 53 & $91.0 \pm 8.7$ & 0.13 \\
\hline CHD patients $(\mathrm{BB}+)$ & 135 & $24.11 \pm 2.94$ & 53 & $24.95 \pm 3.06$ & 0.08 \\
\hline $\mathrm{CHD}$ patients $(\mathrm{BB}+)$ with $\mathrm{AGM}$ & 68 & $24.4 \pm 2.9$ & 27 & $25.7 \pm 2.7$ & 0.05 \\
\hline
\end{tabular}

mozygote for the wild type $(n=111)$. The BMI and sex-adjusted triglyceride concentrations were significantly higher in control subjects carrying the variant $(p<0.01)$. In CHD patients (Table 3$)$, triglyceride concentrations were similar in carriers of the variant $(n=83)$ and in subjects' homozygote for the wild type $(n=226)[1.83(1.22-2.74)$ vs $1.67(1.15-2.38)$ $\mathrm{mmol} / \mathrm{l}, p<0.32]$. The BMI and sex-adjusted triglyceride concentrations were also similar. Crude HDL concentrations (same findings for BMI and sex-adjusted HDL concentrations) were similar in the two genotype groups, both in control subjects and in the CHD patients.

Many of these patients were treated by beta blockers (BB) to prevent further cardiovascular disease
(53\% of the $188 \mathrm{CHD}$ patients treated by BB were hypertensive, $49 \%$ of the 138 patients not treated by $\mathrm{BB}$ were hypertensive, $p<0.47)$. Beta blockers are known to influence triglyceride and HDL concentrations $[13,14]$ and could have a confounding effect on analyses. A comparison of lipid variables, regardless of the genotypes, in patients treated by beta blockers $(\mathrm{BB}+, n=173)$, showed a trend towards higher triglyceride concentrations [1.74 (1.21-2.60) vs 1.58 (1.03-2.24) mmol/l, $p<0.06$ ] and lower HDL concentrations $(0.91 \pm 0.21$ vs $0.95 \pm 0.26 \mathrm{mmol} / 1, p<0.17)$ compared with those who had not been treated (BB-, $n=127)$. We analysed anthropometric measurements, regardless of the genotypes, comparing $\mathrm{CHD}$ patients given $\mathrm{BB}$ treatment with those who 
did not receive $\mathrm{BB}$ treatment: $\mathrm{CHD}(\mathrm{BB}+)$ patients $(n=188)$ had significantly higher waist girth $(89.5 \pm 8.3$ vs $87.0 \pm 9.2 \mathrm{~cm}, p<0.009)$, higher WHR $(0.905 \pm 0.073$ vs $0.888 \pm 0.068, p<0.03)$ and a trend towards higher BMI $(24.35 \pm 2.95$ vs $23.85 \pm 3.66 \mathrm{~kg} /$ $\left.\mathrm{m}^{2}, p<0.09\right)$ than CHD (BB-) patients $(n=138)$.

In $(\mathrm{BB}+)$ patients, taking into account genotype groups (Table 3 ), we found in carriers of the variant a trend towards higher waist girth and higher BMI compared with wild-type homozygote patients. We found that the genotype specific means for waist girth and BMI were significantly higher in $(\mathrm{BB}+)$ patients with AGM who were carriers of the variant than in patients with the wild type $(p \leq 0.05)$.

We analysed the effect of the Trp64Arg variant on both crude (Table 3 ) and BMI and sex-adjusted triglyceride and HDL concentrations in CHD patients according to beta blocker treatment. We found in untreated $\mathrm{CHD}(\mathrm{BB}-)$ patients significantly higher triglyceride concentrations $(p<0.008$ between crude triglyceride concentrations and $p<0.007$ for adjusted triglyceride concentrations) as well as decreased HDL values in the carrier group than in the non-carrier group $(p<0.015$ between crude and $p<0.006$ between adjusted values for HDL). In contrast, in CHD $(\mathrm{BB}+)$ patients, triglyceride concentrations were similar $(p<0.77$ for crude and $p<0.11$ for adjusted triglyceride concentrations) but HDL concentrations were significantly higher in carriers of the variant compared with the non-carriers $(p<0.01$ for crude HDL concentrations and $p<0.002$ for adjusted HDL concentrations).

Using the cut-off values described in the definition of the metabolic syndrome, we studied the association between the different components of the metabolic syndrome (categorical variables) and the Trp64Arg polymorphism and then stratified the analysis for beta-blocker treatment. No association was found between polymorphism and hypertriglyceridaemia when all 307 patients without hypolipaemic treatment were considered together, regardless of their BB treatment status $(p<0.42)$. In CHD (BB-) patients, the variant seemed to be associated with a higher risk of hypertriglyceridaemia $(\mathrm{OR}=2.86, \mathrm{CI}$ : $1.15-7.18, p<0.02)$. In the CHD (BB + ) group, homozygote wild-type patients seemed, however, to be more affected by hypertriglyceridaemia although the association was not significant $(\mathrm{OR}=0.64$, CI: $0.31-1.33, p<0.26)$. A comparison of the two contingency tables shows an interaction between betablocker treatment and the polymorphism for the risk of hypertriglyceridaemia (chi-squared for interaction $=7.53, p<0.006)$.

When CHD patients were considered together, regardless of $\mathrm{BB}$ treatment, no association was found between low-HDL and the Trp64Arg polymorphism $(p<0.95)$. In the $(\mathrm{BB}-)$ group, the variant seemed to be associated with a higher risk for low-HDL

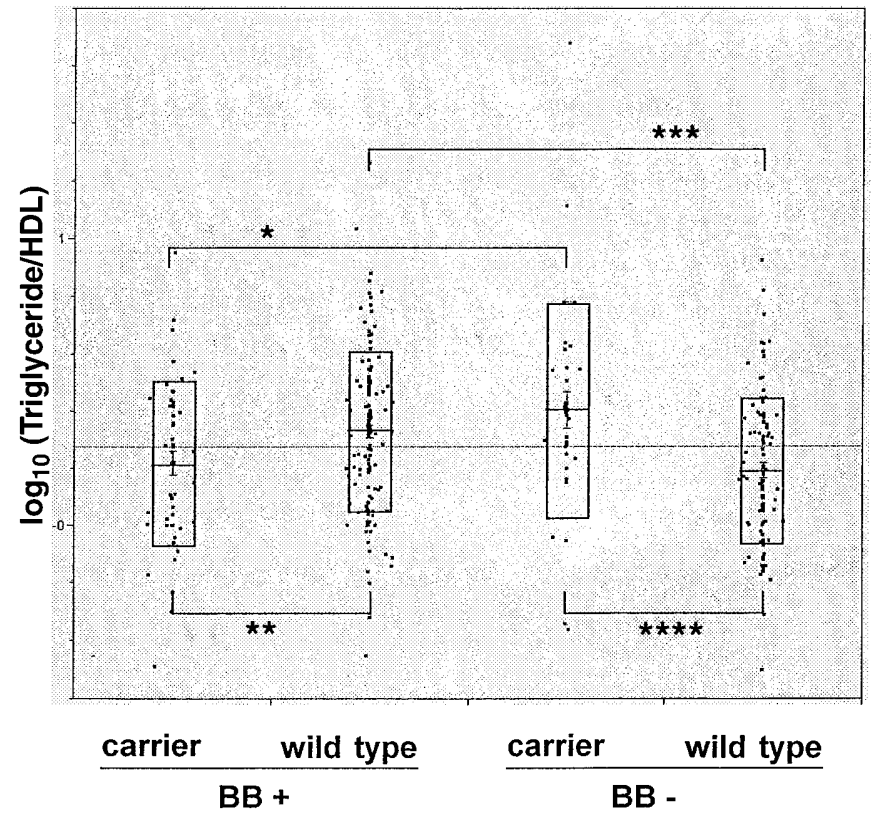

Fig. 1. Scatterplot of $\log _{10}$ (TG:HDL) in CHD patients grouped by $\mathrm{BB}$ treatment and genotypes. Boxes show means $\pm 1 \mathrm{SD}$ for each subgroup. $\mathrm{BB}+$ treated by beta blockers, BB-without treatment. Carriers: TA or AA, wild-type TT. $* p<0.015$; ** $p<0.02$; *** $p<0.0003$; **** $p<0.0006$

$(\mathrm{OR}=3.37, \mathrm{CI}: 1.30-8.92, p<0.009)$, whereas in the $(\mathrm{BB}+)$ group, the variant was associated with a lower risk for low-HDL $(\mathrm{OR}=0.46$, CI: 0.22-0.97, $p<0.04)$. When we compared the two groups, we found an interaction between BB treatment and the Trp64Arg polymorphism on the risk of having lowHDL (chi-squared for the evaluation of interaction $=12.44, p<0.0004$ ).

No association was found between the other components of the metabolic syndrome (microalbuminuria $\geq 20 \mathrm{mg} / \mathrm{l}$, HOMA score $\geq 75$ th centile, central obesity, obesity with BMI $>30 \mathrm{~kg} / \mathrm{m}^{2}$ ) and the Trp64Arg polymorphism, either alone or when stratified for beta-blocker treatment (no association was found either, in stratified analyses for AGM or HBP).

We analysed the $\log _{10}$ triglyceride to HDL transformed ratio ( $\log _{10}$ TG:HDL) as an indicative parameter of triglyceride metabolism impairment, which includes the joint effects of triglyceride and HDL concentrations $[15,16]$. We found that differences in this variable in the genotype groups depended on BB treatment. Because comparisons between BMI and sex-adjusted values for $\log _{10}$ TG:HDL yielded the same differences between groups, we have shown the results for the crude $\log _{10}$ TG:HDL. The most significant difference was found (Fig. 1) between genotypes in the (BB-) group showing an impairment of triglyceride metabolism in the carrier group: $[0.407 \pm 0.380(n=32)$ vs $0.196 \pm 0.258$ in subjects with the wild-type alleles $(n=95) ; p<0.0006]$. An inverse trend was seen in $\mathrm{CHD}(\mathrm{BB}+)$ patients. The 
homozygote wild-type subjects seemed to suffer more from triglyceride metabolism impairment than carriers of the mutation: $[0.331 \pm 0.277$ in wild-type $(n=124)$ vs $0.220 \pm 0.289$ in carriers of the mutation $(n=47), p<0.02]$. When CHD patients with the wild-type genotype were compared according to their $\mathrm{BB}$ treatment, a highly significant impairment of triglyceride metabolism was observed in the $(\mathrm{BB}+)$ group compared with the (BB-) group: $[0.331 \pm 0.277 \quad(n=124)$ vs $0.196 \pm 0.258 \quad(n=95)$, $p<0.0003]$.

\section{Discussion}

In Indo-Mauritian CHD patients we found no association between the Trp64Arg mutation and either CHD, AGM, HBP or the metabolic syndrome. Waist girths and BMI tended to be higher in carriers of the variant in CHD patients who had been treated with $\mathrm{BB}$, especially in those with AGM. Allele frequencies of the Trp64Arg mutation among Indo-Mauritians ( 0.12 in control subjects to 0.14 in coronary heart disease patients) were similar to allelic frequencies found in Mexican-Americans (0.13) and in black Americans (0.12) [4].

We found an effect of the Trp64Arg mutation of the $\beta 3$-adrenergic receptor on triglyceride and HDL concentrations as described in other studies where the Trp64Arg variant has been associated with higher triglycerides and low HDL in Japanese diabetic subjects [8] and in Japanese premenopausal obese women [17]. The Trp64Arg variant has been associated with low HDL in Chinese subjects [18]. Our study shows that triglyceride concentrations, were higher and HDL concentrations were lower in patients who were carriers of the mutation but these differences were only perceptible when BB treatment was excluded. The BB treatment has been reported to cause side effects such as high triglyceride and decreased HDL concentrations, probably because of its antagonistic effects on the lipid metabolism pathway controlled by the sympathetic nervous system. Activation of the sympathetic nervous system increases lipolysis and decreases triglyceride-rich lipoprotein accumulation into white adipose tissue (WAT) by $\beta$ adrenergic receptors, thus reducing fat stores. It has been shown that $\beta 3$-adrenergic receptor systems predominantly contribute to these processes [19, 20,21]. But we note that $\alpha 2$-adrenergic receptors tended to inhibit lipolysis. A blocked $\beta$-adrenergic-receptor pathway could lead to the impairment of triglyceride metabolism explaining the side effects found for triglyceride and HDL concentrations when beta-blocking agents are used or when $\beta$-adrenergic receptors are mutated.

The Trp64Arg mutation is situated in the first intracellular loop of the $\beta 3$-adrenergic receptor, a G- protein coupled receptor with seven transmembrane domain motifs. Mutations in the first cytoplasmic loop of several other G-protein coupled receptors have been shown to alter the receptor function. This part of the protein is especially important for the proper movement of the receptor to the cell surface and for its coupling to the effector system [22].

In vitro studies on $\beta 3$-adrenergic-receptor function showed somewhat contradictory results. A study on Chinese hamster ovary cells showed that the Trp64Arg polymorphism did not lead to a pharmacologically or functionally impaired receptor function [23]. One study measured lipolysis in human isolated visceral white fat cells incubated with noradrenaline or CGP 12177 (selective partial $\beta 3$-agonist), showing that the Trp64Arg mutation in its heterozygous form is not a major determinant of $\beta_{3}$-adrenergic-receptor function [24]. Similarly, studies in Pima Indians, showed that there was no effect of the variant on in vivo lipolysis in subcutaneous adipose tissue [25]. Another study, also on Pima Indians, reported that the Trp64Arg variant even when expressed in its homozygous form, does not affect in vivo or in vitro lipid metabolism (studied in isolated abdominal subcutaneous adipocytes) [26].

Although $\beta 3$-adrenergic receptors are expressed in several human fat depots [27], they have little lipolytic action on the subcutaneous fat tissue [28] but a pronounced lipolytic function in fat cells from the visceral region [19]. Studies carried out with CGP 12177, which is a partial $\beta 3$-adrenergic agonist, are less powerful than those carried out with (L-755,507), a potent and selective human $\beta 3$-adrenergic-receptor agonist. A recent study assessed whether lipolytic activities induced by (L-755,507), CGP12177 or isoproterenol would be affected by the Trp64Arg mutation of the $\beta 3$-adrenergic receptor in human omental adipocytes [29]. No difference was found between the Arg64 homozygous and the wild type, in lipolysis induced by isoproterenol or CGP12177. Lipolytic activities induced by L-755,507 were, however, lower in homozygous Arg64 as well as in heterozygous Trp64Arg compared with wild-type samples, showing a functional effect of the mutation. Another recent study in 3T3L1 mice adipocytes, transfected with the human Trp64Arg variant of the $\beta 3$-adrenoreceptor [30] showed that the mutated receptor caused a lowered response to $\beta 3$-adrenergic agonists such as epinephrine, norepinephrine and L-755,507. The authors concluded that the Trp64Arg mutant $\beta 3$-adrenergic receptor had less ability to stimulate adenylyl cyclase and suggested that lipolytic activity through the $\beta 3$ adrenergic receptor by catecholamines in subjects carrying this mutation might be suppressed.

We showed that Indo-Mauritian CHD patients with the wild type of $\beta 3$-adrenergic receptor have nearly normal triglyceride and HDL concentrations without $\mathrm{BB}$ treatment. The mutation in the $\beta 3$-adren- 
ergic receptor, in the absence of $\mathrm{BB}$ treatment, seems to have the same effect as BB in the absence of the mutation on triglyceride and HDL concentrations in CHD patients. We speculate that firstly, the Trp64Arg mutation impairs the $\beta 3$-adrenergic-receptor function for the triglyceride metabolism. Even if it does not carry a direct risk for coronary heart disease or AGM or IRS, the variant has a modifier effect on this component of the metabolic syndrome, which is apparent in the control group as well. Secondly, beta blockers which are currently used as prophylactic treatment in CHD, seem to impair the $\beta 3$-adrenergic-receptor effect on lipid metabolism when subjects carry only the wild-type allele. Adverse effects of beta-blocker treatment on the lipid profile in CHD patients that do not carry the mutation, have to be weighed against the proven benefits in preventing further cardiovascular disease. Moreover, BMI and waist girth tend to be higher in CHD patients treated with $\mathrm{BB}$, showing an increased propensity towards central obesity in these patients, a factor which aggravates the metabolic syndrome.

The deleterious effect of the Trp64Arg variant on lipid concentrations are masked in some respects by the $\mathrm{BB}$ treatment. In the $\mathrm{CHD}(\mathrm{BB}+)$ group an inverse trend towards higher HDL concentrations was found in carriers of the variant. Our study infers that the Trp64Arg mutation of the $\beta 3$-adrenergic receptor modulates the effects of $\mathrm{BB}$ on lipid profiles of the patients. If the $\mathrm{BB}$ treatment had not been taken into account, the effects of the mutation on dyslipidaemia would have been missed altogether in our group of patients, because of the interaction between the genetic susceptibility and this important environmental factor.

Indo-Mauritian patients with premature CHD have surprisingly normal triglyceride and HDL values when carrying the wild type (TT) of the $\beta 3$-adrenergic receptor unless they are treated with beta blockers. The $\beta 3$-adrenergic-receptor mutation seems to modulate the effects of beta blockers on triglyceride and HDL concentrations in this group of subjects. Dyslipidaemia (high triglyceride, low HDL), which is a key component of the metabolic syndrome, is heterogeneous within Indo-Mauritians. This potent risk factor for the early onset of CHD is influenced by the interaction between genetic and environmental effects.

Acknowledgements. We thank the Ministry of Health in Mauritius for giving permission to recruit patients with premature coronary heart disease. We thank Dr V. Balgobin, Dr K.T. Gunness, Dr N. Domah, Dr R. Dhuny, Dr A. Yearoo, Dr B. Gopaul, Dr R. Tennant, Mr S. Kamudu, Mr D. Bacosse, Mr O. Rampadaruth for their administrative assistance. We thank Dr F. Leprêtre from CNRS UPRES A 8090, Lille who provided primers and enzymes. We thank the following persons from SSR Centre, Mauritius: Mr I. Ramracheya, Mr V. Soomaree for helping us recruit control subjects, Mrs S. Jankee and Mrs S. Lee Kwai Yan for their helpful technical assistance.

\section{References}

1. Mc Keigue PM, Miller GJ, Marmot MG (1989) Coronary heart disease in south Asians overseas: A review. J Clin Epidemiol 42(7): 597-609

2. Mc Keigue PM, Shah B, Marmot M.G (1991) Relation of central obesity and insulin resistance with high diabetes prevalence and cardiovascular risk in South Asians. Lancet 337: 382-386

3. Zimmet P-Z, Collins V-R, Dowse G-K et al. (1994) Is hyperinsulinemia a central characteristic of a chronic cardiovascular risk factor clustering syndrome? Mixed findings in Asian, Creole and Chinese Mauritians. Diabet Med 11: 388-396

4. Walston J, Silver K, Bogardus C et al. (1995) Time of onset of non-insulin-dependent diabetes mellitus and genetic variation in the beta 3-adrenergic-receptor gene. N Engl J Med 333: 343-347

5. Widen E, Lehto M, Kanninen T, Walston J, Shuldiner A-R, Groop L-C (1995) Association of a polymorphism in the $\beta_{3^{-}}$ adrenergic-receptor gene with features of the insulin resistance syndrome in Finns. N Engl J Med 333: 348-351

6. Clément K, Vaisse C, Manning B-S-J et al. (1995) Genetic variation in the Beta-3 adrenergic-receptor and an increased capacity to gain weight in patients with morbid obesity. N Engl J Med 333: 352-354

7. Mitchell B-D, Blangero J, Comuzzie A-G et al. (1998) A paired sibling analysis of the Beta-3 Adrenergic Receptor and obesity in Mexican Americans. J Clin Invest 101: 584-587

8. Sakane N, Yoshida T, Yoshioka K et al. (1998) $\beta_{3}$-adrenoreceptor gene polymorphism: A newly identified risk factor for proliferative retinopathy in NIDDM patients. Diabetes 46: 1633-1636

9. WMA's Declaration of Helsinki (1997). Recommendations guiding physicians in biomedical research involving human subjects. JAMA 277: 925-926

10. Matthews DR, Hosker JP, Rudenski AS, Naylor BA, Treacher DF, Turner RC (1985) Homeostasis model assessment: insulin resistance and $\beta$-cell function from fasting plasma glucose and insulin concentrations in man. Diabetologia 28: 412-419

11. Report of a WHO Consultation (1999) The Metabolic Syndrome. In: Definition, diagnosis and classification of diabetes mellitus and its complications. WHO/NCD/NCS/99.2: 31-33

12. Bonora E, Targher M, Alberiche M et al. (2000) Homeostasis model assessment closely mirrors the glucose clamp technique in the assessment of insulin sensitivity: studies in subjects with various degrees of glucose tolerance and insulin sensitivity. Diabetes Care 23: 57-63

13. Reneland R, Alvarez E, Andersson PE, Haenni A, Byberg L, Lithell H (2000) Induction of insulin resistance by betablocker treatment but not ACE-inhibition: long term treatment with atenolol or trandolapril. J hum Hypertens 14: 175-180

14. Andersen P, Seljeflot I, Herzog A, Arnesen H, Hejrmann I, Holme I (1998) Effects of doxazosin and atenolol on atherothrombogenic risk profile in hypertensive middle-aged men. J Cardiovasc Pharmacol 31: 677-683

15. Mahaney MC, Blangero J, Comuzzie AG, VandeBerg JL, Stern MP, MacCluer JW (1995) Plasma HDL cholesterol, triglycerides and adiposity. A quantitative genetic test of the conjoint trait hypothesis in the San Antonio Family Heart Study. Circulation 92: 3240-3248

16. Senti M, Aubo C, Elosua R, Sala J, Tomas M, Marrugat J (2000) Effect of physical activity on lipid levels in a popula- 
tion-based sample of men with and without the Arg192 variant of the human paraoxonase gene. Genet Epidemiol 18(3): 276-286

17. Sakane N, Yoshida T, Umekawa T, Kondo M, Sakai Y, Takahashi T (1997) $\beta 3$-adrenergic-receptor polymorphism: a genetic marker for visceral fat obesity and the insulin resistance syndrome. Diabetologia 40: 200-204

18. Thomas GN, Tomlinson B, Chan JC, Young RP, Critchley JA (2000) The Trp64Arg polymorphism of the beta3adrenergic receptor gene and obesity in Chinese subjects with components of the metabolic syndrome. Int $\mathrm{J}$ Obes Relat Metab Disord 24: 545-551

19. Lönnqvist F, Thörne A, Nilsell K, Hoffstedt J, Arner P (1995) A pathogenic role of visceral fat beta3-adrenoceptors in obesity. J Clin Invest 95: 1109-1116

20. Hoffstedt J, Wahrenberg H, Thörne A, Lönnqvist F (1996) The metabolic syndrome is related to beta3-adrenoceptor sensitivity in visceral adipose tissue. Diabetologia 39: 838-844

21. Nonogaki K (2000) New insights into sympathetic regulation of glucose and fat metabolism. Diabetologia 43: 533-549

22. Birnbaumer M (1995) Mutations and diseases of $G$ protein coupled receptors. J Recept Signal Transduct Res 15: 131-160

23. Candelore MR, Deng L, Tota LM, Kelly LJ, Cascieri MA, Strader CD (1996) Pharmacological characterization of a recently described human beta3-adrenergic receptor mutant. Endocrinology 137: 2638-2641

24. Li L.S, Lönnqvist F, Luthman H, Arner P (1996) Phenotypic characterization of the Trp64Arg polymorphism in the beta $_{3}$-adrenergic receptor gene in normal weight and obese subjects. Diabetologia 39: 857-860

25. Snitker S, Odeleye OE, Hellmer J et al. (1997) No effect of the Trp64Arg $\beta 3$-adrenoceptor variant on in vivo lipolysis in subcutaneous adipose tissue. Diabetologia 40: 838-842

26. Tataranni PA, Pratley R, Shuldiner A, Ravussin E (1997) $\beta 3$-adrenergic receptor variant and lipid metabolism in Pima Indians. Diabetologia 40: 123-124

27. Krief S, Lönnquist F, Raimbault S et al. (1993) Tissue distribution of $\beta 3$ adrenergic receptor mRNA in man. J Clin Invest 91: 344-349

28. Rosenbaum M, Malbon CC, Hirsch J, Leibel RL (1993) Lack of $\beta 3$-adrenergic effect on lipolysis in human subcutaneous adipose tissue. J Clin Endocrinol Metab 77: 352-355

29. Umekawa T, Yoshida T, Sakane N, Kogure A, Kondo M, Honjyo H (1999) Trp64Arg mutation of beta3-adrenoceptor gene deteriorates lipolysis induced by beta3-adrenoceptor agonist in human omental adipocytes. Diabetes 48 (1): 117-120

30. Kimura K, Sasaki N, Asano A et al. (2000) Mutated human beta3-adrenergic receptor (Trp64Arg) lowers the response to beta3-adrenergic agonists in transfected 3T3-L1 preadipocytes. Horm Metab Res 32(3): 91-96 